\title{
ASSESSMENT OF GENETIC DIVERSITY AND GENETIC RELATIONSHIPS AMONG SEVEN CHILEAN CHESTNUT (Castanea sativa MILL.) POPULATIONS USING ISOZYMES AND RAPD MARKERS
}

\author{
V. Loewe'; C. Mattioni²; M. González'; M. Cherubini²; P. Pollegioni²; \\ F. Villani²; M. Casasoli; S. Benedetti'
}

\section{SUMMARY}

This paper estimates the genetic variability of 7 seed propagated Chilean populations of Castanea sativa Mill. using isozymes and RAPD markers. Out of 17 isozymes loci investigated 41 alleles were detected, 4 RAPD primers generated 37 markers. Low genetic intra populations variability was estimated using isozymes ( Fis 0.027$)$ and RAPD $(\mathrm{Hs}=0.02)$ markers. Although the geographical distance from populations is considerable the differentiation among them is not high: Gst $=0.095$ for RAPD and Fst 0.101 for isozymes. Not deviations from Hardy Weinberg equilibrium was estimated, even though these populations had received selective pressure and were introduced recently to Chile, probably during the 19th with the arrival of European immigrants. UPGMA analysis, based on Nei genetic distance index and including isozymes data of previously studied European populations, suggests Portugal as the possible center of origin of Chilean Chestnut populations. The generated information represents an important contribution to local managers and authorities, to determine an appropriate chestnut management, combining productivity and conservation, economy and ecology.

Key Words: Chestnut, Genetic diversity, Isozymes, RAPDs.

\footnotetext{
1Instituto Forestal.Chile.vloewe@infor cl, mgonzale@infor cl.sbenedet@infor cl

2Istituto di Biologia Agroambientale e Forestale Italy. c mattioni@ ibaf cnr.it
} 


\section{ANALISIS DE LA DIVERSIDAD Y RELACIONES GENÉTICAS ENTRE SIETE POBLACIONES CHILENAS DE CASTAÑO (Castanea sativa Mill.) USANDO ISOENZIMAS Y MARCADORES MOLECULARES RAPD}

\section{RESUMEN}

Se utiliza isoenzimas y marcadores moleculares (RAPD) para estimar la variabilidad genética de 7 poblaciones chilenas de castaño (Castanea sativa Mill.) propagadas por semilla. De 17 loci isoenzimáticos analizados se detectaron 41 alelos; 4 partidores RAPDs generaron 37 marcadores. Se detectó una baja variabilidad genética dentro de las poblaciones usando isoenzimas $(F I S=0,027)$ y marcadores RAPD $(H s=0,02)$. Aunque la distancia geográfica entre las poblaciones es considerable, la diferenciación entre ellas no es alta: Gst $=0,095$ para RAPD y Fst $=0,101$ para las isoenzimas. No se estimaron desviaciones para ley de equilibrio de Hardy-Weinberg, aún cuando estas poblaciones habian estado sometidas a presiones de selección y habian sido introducidas a Chile recientemente, probablemente durante el Siglo XIX con la llegada de los emigrantes europeos. El análisis UPGMA basado en el indice de distancia genética de Nei, e incluyendo información de isoenzimas estudiados previamente en poblaciones europeas, sugieren a Portugal como el posible centro de origen de las poblaciones chilenas de castaño. La información generada representa una importante contribución a los silvicultores y autoridades locales para determinar un apropiado manejo del castaño, que combine aspectos de productividad con otros de conservación, economia y ecologia.

Palabras clave: Castaño, diversidad genética, isoenzimas, RAPD 


\section{INTRODUCTION}

Since immemorial times the Chestnut tree, Castanea sativa Mill, has represented a valued productive alternative, both for its fruit and timber. From the antiquity its timber was recognized for its nobility, used as structural wood, for furniture and fine handicrafts, and in agricultural applications (Benedetti and Subiri, 2000). Its fruits became a currency in periods of shortage, due to its excellent nutrition, reason why special varieties have been developed for the production of high quality Chestnuts, oriented to gourmet markets.

Its presence in Chile goes back to 19th century, when European immigrants introduced it to the country (Benedetti and Subiri, 2000). In Chile Chestnut has been cultivated in the central and southern area, where some commercial orchards are found. In general, orchards do not present a defined management, and irrigation, fertilizers and herbicides are not usually applied, bearing low quality fruit (Loewe et al., 1994). Contrarily, Chestnut timber presents good technological characteristics; no ring-shake defect has been found in the country (Loewe et al., 1994).

Furthermore, based on the ecological requirements of the species and environmental characteristics in Chile, potential areas of approximately 1.400 .000 hectares for the establishment of plantations were determined (Loewe et al., 1997).

Considering the wide geographical distribution of this species, the diversity of the identified phenotypes (Benedetti and Subiri, 2000) and the economic importance of this species, studies on genetic variability of Chestnut in Chile are needed.

The aims of this work were: 1) Evaluate the genetic diversity of the Chilean Chestnut populations using isozymes and RAPD markers 2) Evaluate the possible origin of Chilean Chestnut populations analyzing the isozymes data obtained in this study with those previously published by Villani et al. (1994). This information can be the base of a strategy of genetic improvement oriented to plantations with forest and fruit-forest goals, as well as to define utilization and germplasm conservation criteria, both basic factors to take advantage of the potentiality of the species in Chile.

\section{MATERIALS AND METHODS}

\section{Plant Material}

Samples of Chestnut fruits were collected from 30 trees coming from each of seven populations located between the VIII and X Regions of Chile. Four of the seven analyzed populations aim at fruit-bearing production, while the three remaining aim at timber productions (Table $\mathrm{N}^{\circ}$ 1). All plantations were seed propagated. 
Table $N^{\circ} 1$

CHARACTERIZATION AND GEOGRAPHICAL LOCALIZATION OF THE STUDIED POPULATIONS

\begin{tabular}{|c|c|c|c|c|c|c|c|}
\hline Property Name & Region & County/City & $\begin{array}{l}\text { Lat (S); } \\
\text { Long (W) }\end{array}$ & $\begin{array}{c}\text { Plantation's } \\
\text { goal }\end{array}$ & $\begin{array}{c}\begin{array}{c}\text { Age } \\
\text { (years) }\end{array} \\
\text { year }\end{array}$ & $\begin{array}{l}\text { Spacing } \\
(m)\end{array}$ & Soil Type \\
\hline Tanilboro & VIII & Coihueco & $34^{\circ} 40^{\prime} 71^{\circ} 50^{\prime}$ & Fruit & 50 & $12 \times 12$ & Trumao $^{3}$ \\
\hline Santa Cecilia & VIII & San Ignacio & $37^{\circ} 00^{\prime} 72^{\circ} 00^{\prime}$ & Fruit & 50 & $10 \times 10$ & Trumao \\
\hline Trehualemu & VIII & San Ignacio & $37^{\circ} 00^{\prime} 72^{\circ} 00^{\circ}$ & Fruit & $45-50$ & $10 \times 10$ & Trumao \\
\hline El Coigüe & IX & Villarrica & $39^{\circ} 30^{\prime} 72^{\circ} 30^{\prime}$ & Forest & 29 & $4 \times 4$ & Thin Trumao \\
\hline Las Palmas & $x$ & Valdivia & $40^{\circ} 00^{\prime} 73^{\circ} 00^{\prime}$ & Forest & 41 & $5 \times 5$ & Thin Trumao \\
\hline Los Copihues & $x$ & Valdivia & $40^{\circ} 00^{\prime} 73^{\circ} 00^{\prime}$ & Forest & 34 & $4 \times 4$ & Metamorphic rock \\
\hline Tres Bocas & $x$ & Corral & $40^{\circ} 00^{\prime} 73^{\circ} 00^{\prime}$ & Forest & 26 & $3 \times 3$ & Metamorphic rock \\
\hline
\end{tabular}

Source: Modified of Loewe et al. (1994)

a Trumao: volcanic soil, light, deep, fertile and with good drainage.

\section{Isozymes Analysis}

Starch gel electrophoresis was carried out according to the methodology of Villani et al. (1991). The following eleven enzyme systems were examined (Table $\mathrm{N}^{\circ} 2$ ): alcohol dehydrogenase (Adh, E.C.1.1.1.1), diaphorase (Dia, E.C.1.6.4.3), isocitrate dehydrogenase (Idh, E.C.1.1.1.42), glutamateoxaloacetatetransaminase(Got,E.C.2.6.1.1), phosphoglucomutase(Pgm,E.C.2.7.5.1), leucinelaminopeptidase (Lap, E.C.3.4.11.1), esterase (Est, E.C.3.1.1.2) phosphoglucoisomerase (Gpi, E.C.5.3.1.9), peroxidase (Prx, E.C.1.11.1.17), superoxide dismutase (Sod, E.C.1.15.1.1) and glucose-6-phosphate dehydrogenase (6-Pgdh, E.C.1.1.1.49).

Table $\mathbf{N}^{\circ} 2$

ENZYMATIC SYSTEMS, LOCI AND ALLELES NUMBER

\begin{tabular}{|c|c|c|}
\hline $\begin{array}{c}\text { Enzymatic } \\
\text { systems }\end{array}$ & $\begin{array}{c}\text { Loci } \\
\text { enzymatic }\end{array}$ & $\begin{array}{c}\text { Alleles } \\
\text { Number }\end{array}$ \\
\hline ADH & Adh & 3 \\
\hline DIA & Dia & 2 \\
\hline \multirow{2}{*}{ IDH } & Idh-1 & 4 \\
& Idh-2 & 2 \\
\hline \multirow{2}{*}{ GOT } & Got-1 & 1 \\
& Got-2 & 1 \\
\hline PGM & Got-3 & 2 \\
\hline \multirow{2}{*}{ LAP } & Pgm & 2 \\
\hline EST & Lap-1 & 5 \\
\hline \multirow{2}{*}{ GPI } & Lap-3 & 4 \\
\hline GPGDH & Gpi-1 & 3 \\
\hline PRX & Gpi-2 & 3 \\
\hline SOD & Prx-1 & 3 \\
\hline
\end{tabular}




\section{DNA Extraction and RAPD Amplification}

DNA was extracted from $100 \mathrm{mg}$ of nut tissue according to Doyle and Doyle (1987) method. 18 RAPD primers, obtained from Operon Technology (Alameda Calif.), were tested. Four of these (OPM 7, OPT 2, OPK 4, and OPK 19) showed clear and reproducible bands were used for the analysis (Table $\mathrm{N}^{\circ} 3$ ). Amplifications were made in $12.5 \mu \mathrm{l}$ of reaction volume containing $10 \mathrm{mM}$ Tris- $\mathrm{HCl} \mathrm{pH} \mathrm{8;} 50 \mathrm{mM} \mathrm{KCl} ; 1.5 \mathrm{mM} \mathrm{MgCl} 20.2 \mathrm{mM}$ of each dNTP: $0.4 \mu \mathrm{M}$ primer; $100 \mathrm{mg} / \mathrm{ml} \mathrm{BSA}$ : 0.75 Unit of Taq-polymerases (Boeringer Mannheim. Germany) and $20 \mathrm{ng}$ of DNA. The mixture was overlaid with mineral oil and subjected to PCR on a Perkin Elmer 480 Thermal Cycler programmed for an initial step of 3 minutes at $94^{\circ} \mathrm{C}$, followed by 45 cycles at the following temperatures: $94^{\circ} \mathrm{C}$ for 1 minute, $36^{\circ} \mathrm{C}$ for 1 minute, $72^{\circ} \mathrm{C}$ for 2 minutes and a final step at $72^{\circ} \mathrm{C}$ for 10 minutes. Amplification products were analyzed on a $1.4 \%$ agarose gel stained with ethidium bromide $(0.2 \mu \mathrm{g} / \mathrm{l})$.

Table 3

RAPD PRIMERS USED AND NUMBER OF MARKERS SCORED

\begin{tabular}{|c|c|c|c|}
\hline Primer & $\begin{array}{c}\text { Sequence } \\
\left(\mathbf{5}^{\prime}-\mathbf{3}^{\prime}\right)\end{array}$ & $\begin{array}{c}\text { Number of } \\
\text { scored bands }\end{array}$ & $\begin{array}{c}\text { Scored bands } \\
\text { molecular weight } \\
\text { range }\end{array}$ \\
\hline OPM 7 & CCGTGACTCA & 12 & $475-1273$ \\
\hline OPT 2 & GGAGAGACTC & 8 & $525-1230$ \\
\hline OPK 4 & CCGCCCAAAC & 13 & $271-1538$ \\
\hline OPK 19 & CACAGGCGGA & 4 & $984-1476$ \\
\hline
\end{tabular}

\section{Data Analysis}

Isozymes

Isozymes were progressively numbered from the most anodally migrating one. Data were statistically processed using software BIOSYS-1 (Swofford and Selander, 1989) and POPGENE (Yeh et al., 1997). The percentage of polymorphic loci $(P)$ and the number of expected $(\mathrm{He})$ and observed $(\mathrm{Ho})$ heterozygotes were calculated.

Genetic differentiation within and between the Chilean populations was estimated by $F$ statistics (Fst, Fit and Fis) (Weir and Cockerham, 1984) using FSTAT software (Goudet, 2000).

In order to determine the possible origin of the Chilean chestnut, F-statistics analysis was also used to compare isozymes data of Chilean populations with isozymes data of European chestnut populations (Italy, Portugal, Spain and Turkey) previously published (Villani et al., 1994). Cluster analysis of the dissimilarity matrices, based on Nei (1978) genetic diversity index, was performed and the results summarized as UPGMA analysis. A Wagner tree was generated to highlight the genetic distance between Chilean and European populations. Mantel test was curried out to correlate genetic and geographic distances.

RAPD

The band indicated with the primer code and the molecular weight (bp) were read considering presence $(=1)$ and absence $(=0)$. For RAPD markers, being dominant, the null homozygotes can 
be identified by the absence of any amplified product and the frequency of the two alleles at a RAPD locus could be calculated from the frequency of null phenotypes $\left(q^{2}\right)$ and $p=1-q$.

Bands with extremely low recessive frequencies $\left(q^{2}<3 / n\right)$ were excluded from the analysis (Lynch and Milligan, 1994).

Using the software POPGENE (Yeh et al., 1997), a set of measures of intra and inter genetic population statistics were calculated: percentage of polymorphous loci $(\mathrm{P})$, total genetic diversity $(\mathrm{Ht})$, genetic diversity within population ( $\mathrm{Hs}$ ) and genetic differentiation among populations (Gst). Cluster analysis based on Nei (1978) genetic distance values was performed using UPGMA method. To validate the correspondence of genetic and geographic distances, a Mantel test was carried out.

\section{RESULTS}

Of 17 isoenzyme loci investigated 41 alleles were detected while the four RAPD primers used generated 37 markers. Tables' 4 and 5 show the genetic diversity values of the seven Chilean Chestnut populations obtained respectively with isozymes and RAPD data.

Table $N^{\circ} 4$

GENETIC DIVERSITY VALUES BASED ON ISOZYMES DATA

\begin{tabular}{|c|c|c|c|c|c|}
\hline Single Population & $\begin{array}{c}\text { Shannon's } \\
\text { information index }\end{array}$ & $\begin{array}{c}\text { loci polymorphic } \\
(\%)\end{array}$ & Ho & He & Fis \\
\hline Tres Bocas & $0.43(0.27)$ & 52.9 & $0.217(0.053)$ & $0.236(0.054)$ & 0.081 \\
\hline Tanilboro & $0.41(0.30)$ & 70.6 & $0.242(0.054)$ & $0.242(0.051)$ & 0.001 \\
\hline Las Palmas & $0.40(0.40)$ & 47.1 & $0.192(0.051)$ & $0.225(0.061)$ & 0.150 \\
\hline Santa Cecilia & $0.35(0.29)$ & 58.8 & $0.180(0.042)$ & $0.196(0.045)$ & 0.082 \\
\hline El Coigüe & $0.40(0.35)$ & 58.8 & $0.242(0.058$ & $0.232(0.053)$ & -0.001 \\
\hline Trehualemu & $0.37(0.26)$ & 64.7 & $0.209(0.042)$ & $0.213(0.043)$ & 0.021 \\
\hline Los Copihues & $0.43(0.39)$ & 58.8 & $0.239(0.056)$ & $0.234(0.057)$ & -0.012 \\
\hline All populations & Fis & $\mathbf{F t}$ & Fst & & \\
\hline & $0.027(0.082)$ & $0.125(0.072)$ & $0.101(0.036)$ & & \\
\hline
\end{tabular}

Table $N^{\circ} 5$

GENETIC DIVERSITY VALUES BASED ON RAPD DATA

\begin{tabular}{|c|c|c|c|}
\hline Single Populations & $\begin{array}{c}\text { Shannon's } \\
\text { information index }\end{array}$ & $\begin{array}{c}\text { Nei's gene } \\
\text { diversity }\end{array}$ & $\begin{array}{c}\text { Polymorphic loci } \\
\text { (\%) }\end{array}$ \\
\hline Tres Bocas & $0.41(0.26)$ & $0.274(0.189)$ & 78.38 \\
\hline Tanilboro & $0.44(0.26)$ & $0.298(0.189)$ & 81.08 \\
\hline Las Palmas & $0.42(0.27)$ & $0.291(0.196)$ & 78.38 \\
\hline S. Cecilia & $0.47(0.25)$ & $0.324(0.183)$ & 81.08 \\
\hline El Coigüe & $0.49(0.22)$ & $0.333(0.169)$ & 89.19 \\
\hline Trehualemu & $0.46(0.23)$ & $0.309(0.172)$ & 83.78 \\
\hline Los Copihues & $0.46(0.24)$ & $0.313(0.171)$ & 81.08 \\
\hline All populations & Hs & Ht & Gst \\
\hline & $0.34(0.02)$ & $0.30(0.02)$ & 0.095 \\
\hline
\end{tabular}


A higher percentage of polymorphic loci were obtained using RAPD markers (range from 73 to $81 \%$ ) compared to that obtained using isozymes markers (range between 47 and $71 \%$ ).

Comparable genetic diversity values were obtained analyzing the single populations with both markers. In general low intra population diversity and low divergence between populations were obtained respectively for isozymes $(\mathrm{Fis}=0.027 \mathrm{Fst}=0.10)$ and $\mathrm{RAPD}(\mathrm{Hs}=0.34 \mathrm{Gst}=$ 0.095) markers. Higher values of the Shannon's information index were obtained using RAPDs than isozymes markers. Nei genetic diversity values obtained using RAPD markers varied between 0.274 and 0.313 ; the observed average heterozygosity values obtained using isozymes ranged between 0.180 and 0.239 . A moderate deviation from the Hardy Weiber equilibrium was observed only in three populations (Santa Cecilia, Tres Bocas, Las Palmas).

Figures $\mathrm{N}^{\circ} 1$ and 2 show the results of the UPGMA cluster analysis based on Nei (1978) genetic diversity index using, respectively, isozymes and RAPD data. In the dendrogram based on isozymes data (Figure $\mathrm{N}^{\circ} 1$ ), two main groups are identified, one including Las Palmas and Los Copihues populations, the other including Santa Cecilia, Trehualemu, Tres Bocas, El Coigüe, with Tanilboro being intermediate between the two groups. Cluster analysis based on the RAPD values gave different indications; Los Copihues appeared the most differentiated population; the other populations were grouped in two main clusters, one including Tres Bocas, Tanilboro and Las Palmas, and the other including Santa Cecilia, El Coigüe and Trehualemu (Figure $\mathrm{N}^{\circ}$ 2).

Low genetic distances values among populations were observed for both markers.

Mantel test performed between genetic distance and geographic distance showed a low but significant correlation $(r=0.5333$ and $p=0.019)$ for isozymes analysis, while RAPD data underlined the absence of correlation between genetic and geographic distances $(r=0.007, p$ $=0.47$ ).

Genetic differentiation was also estimated between Chilean and European populations analyzing the present isozymes data with those previously published (Villani et al., 1994).

The variability intra (Fs) and among (Fst) populations were low when the Chilean populations were pooled with Portuguese $(F s t=0.100)$ or Italian populations $(0.115)$ while higher values of differentiation were observed pooling the Chilean populations with the Spanish $(0.150)$ or the Turkish ones $(0.174)$ Table $N^{\circ} 6$. The UPGMA cluster analysis (Figure $\mathrm{N}^{\circ} 3$ ) performed with European (Villani et al. 1994) and Chilean populations showed three major clusters; one grouping the Chilean $(C)$ and the Portuguese $(P)$ populations; one grouping the Italian (I) populations and the third one grouping the populations from Spain (E) and Eastern (Te), Central (Tc) and Western Turkey (Tw) populations. 


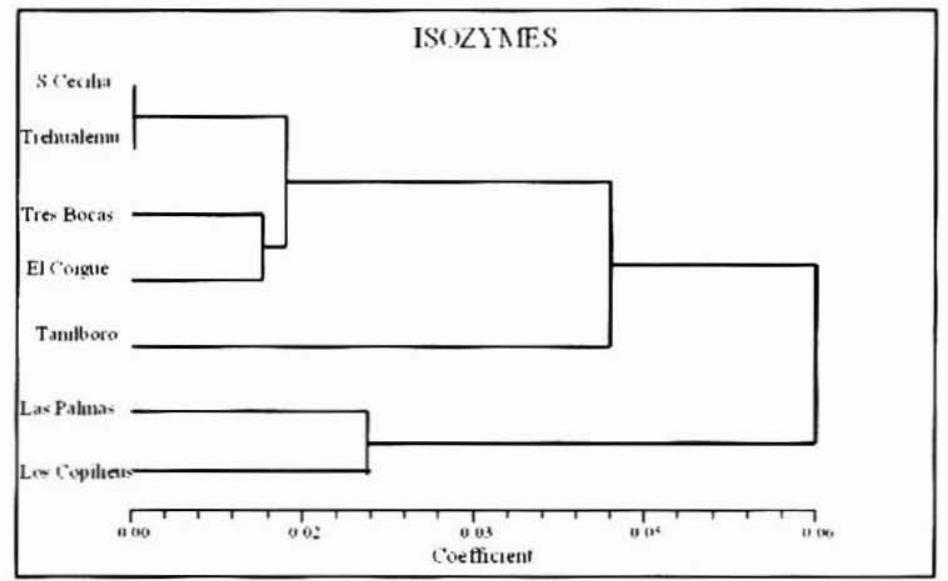

Figure $\mathrm{N}^{\circ} 1$

PGMA DENDROGRAM BASED ON NEI (1978) GENETIC DISTANCE VALUES

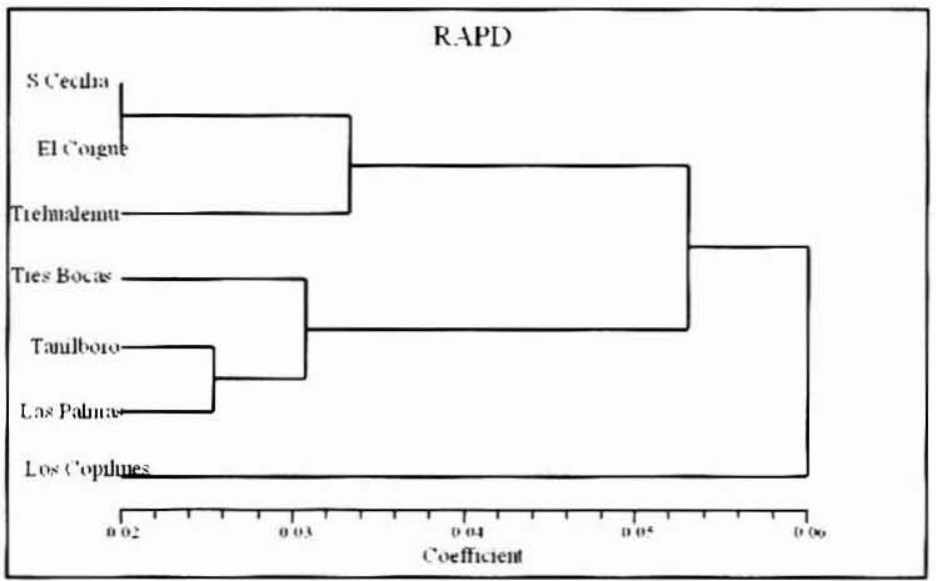

Figure $\mathbf{N}^{\circ} 2$

UPGMA DENDROGRAM BASED ON NEI' (1978) GENETIC DISTANCE VALUES

Table $\mathbf{N}^{\circ} 6$

F -STATISTICS VALUES FOR CHESTNUT POPULATIONS

\begin{tabular}{|c|c|c|c|}
\hline & Fis & Fit & Fst \\
\hline Chile & $0.027(0.082)$ & $0.125(0.072)$ & $0.101(0.036)$ \\
\hline Chile-Portugal & $0.024(0.033)$ & $0.122(0.043)$ & $0.100(0.016)$ \\
\hline Chile-Italy & $0.024(0.021)$ & $0.131(0.036)$ & $0.115(0.026)$ \\
\hline Chile-Spain & $0.036(0.026)$ & $0.180(0.024)$ & $0.150(0.025)$ \\
\hline Chile-Turkey & $0.044(0.019)$ & $0.211(0.033)$ & $0.174(0.033)$ \\
\hline
\end{tabular}




\section{DISCUSSION AND CONCLUSIONS}

This study on Chilean populations indicated a rather low degree of intra populations' genetic diversity and low differentiation among them. Both isozymes and RAPDs markers, despite their different nature revealed comparable genetic structure of the Chilean populations.

In fact isozymes are co dominant, the number of loci analyzed is limited and the variation is detected only in the coding loci, while RAPDs are dominant and provide a large number of anonymous loci but probably located on non coding sequence (Le Corre et al., 1997). This agreement found between isozymes and RAPD markers was also notices in studies of various species (Haig et al., 1994; Yeh et al., 1995; Le Corre et al., 1997; Huang et al., 1998).

The genetic structure of Chilean populations could indicate that the seed sources used for the plantations were derived from rather heterogeneous populations and not from few highly selected genotypes. The low intra population genetic variation as well as the moderate deviation from the Hardy Weinberg equilibrium found in some populations could be interpreted as a result of: (i) relatively recent establishment of the populations which did not have enough time to evolve and adapt to different environmental conditions present in different Chilean regions and not being submitted to strong selective pressure by human action; (ii) introduction from a rather small part of the European Chestnut distribution area which results in populations with a genetic structure not completely representative of the genetic diversity present in the main species origin area.

Compared to the European Chestnut populations the Chilean appear to be less variable (Villani et al., 1995; 1999) and the lowest genetic distance values found between Chilean and Portuguese populations could suggest that Chilean populations have probably originated from the second ones.

This hypothesis is also supported by the genetic structure analysis: the lowest Fst value was found between Chilean-Portuguese populations, the Fst values increases when the Chilean populations are compared with the Italian, Spanish and Turkish populations. According to some palynological and historical records Portuguese populations seem to represent one of the European Chestnut refugia or secondary diversification centers (Villani et al., 1990; 1999). In fact, apparently, the woody species survived the last glaciation in a minimum of three places, one in east Turkey, a second in west Turkey and a third in the Iberian Peninsula, which would correspond to the origin of the Chilean populations, conferring them different characteristics from the rest of the European populations.

The generated information represents an important contribution to local managers and authorities whose main objective is to extend the cultivation of Chestnut to areas potentially appropriate for the species requirements (climate, soil, altitude, etc.). If the cultivation were going to be developed considering sustainability criteria, knowledge on the genetic diversity and the adaptive potential of the populations used would be an essential part of it.

Different approaches could be proposed to delineate an integrated conservation and exploitation strategy. One of the possible strategies could be to test the Chestnut genetic 
resources present in Chile in different geographic regions, possibly through comparative field trials where it would be possible to detect differential adaptation and production capacity within the Chilean gene pool.

Another option would be to explore the possibility to increase the genetic diversity of the Chilean populations through the introduction of material genetically representative of the European Chestnut populations that have not been explored so far. Comparative field trials could be used to test the adaptive potential of this material in the Chilean environmental conditions. Such approach should be a prerequisite for a correct exploitation program both for fruit and wood production and to define with scientific basis how Chestnut management could be applied appropriately, combining productivity and conservation, economy and ecology. 


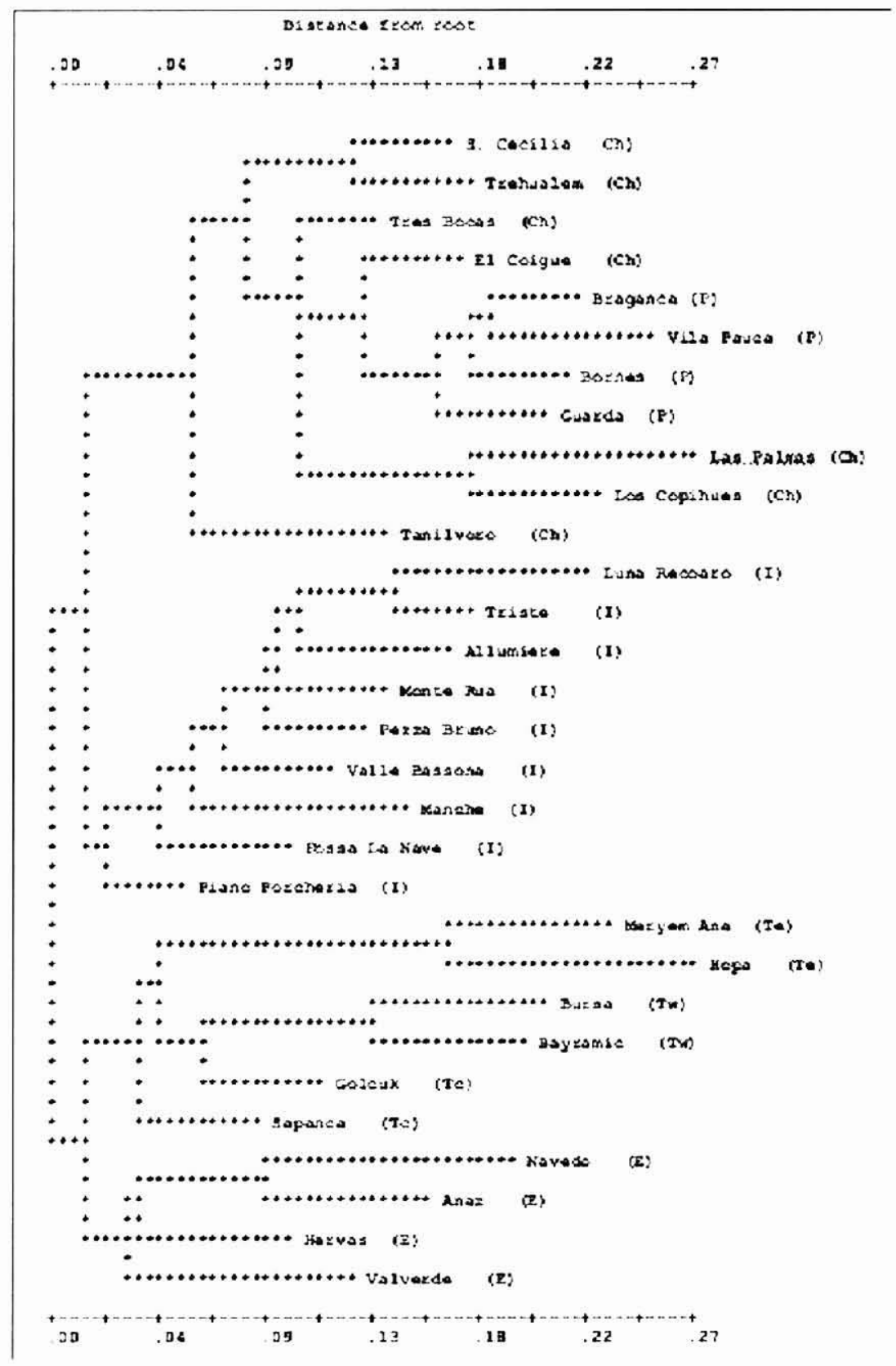

Figure $\mathrm{N}^{\circ} 3$

WAGNER TREE PRODUCED BY ROOTING AT MIDPOINT OF LONGEST PATH 


\section{ACKNOWLEDGEMENTS}

The study was developed between 1997 and 2000 through International Scientific Cooperation. CONICYT (Chile)-CNR (Italy) programs "Study of the genetic structure of Chestnut and Walnut populations for its application into genetic breeding programs and culture techniques valid for noble species" (1999-2000), and "Study of the genetic structure of Chestnut populations to develop conservation, productive exploitation and genetic improvement" (1997-1998). Both initiatives were supported by the R\&D projects "Silviculture of non-traditional species: a higher productive diversity" funded by the Foundation for the Agriculture Innovation (FIA), and "Diversification of forest plantations with species of economic interest", funded by FONDEF.

\section{REFERENCES}

Benedetti, S. and Subiri, M. 2000. El castaño, una opción de producción forestal. Instituto Forestal (INFOR). Chile.

Doyle, J.J. and Doyle, J.L. 1987. A rapid isolation procedure for small quantities of fresh leaf tissue. Phytochem Bull 19:11-15.

Goudet, J. 2000. FSTAT, a program to estimate and test gene diversities and fixation indices (version2.9.1). In: http://www.unil.ch/izea/softwares/fstat.html.

Haig, S.M.; Rhymer, J.M. and Heckel, D.G. 1994. Population differentiation randomly amplified polymorphic DNA of red-cockade woodpeckers Picoides borealis. Mol. Ecol. 3: 581-595.

Huang, H.; Dane, F. and Kubisiak, T.L. 1998. Allozyme and RAP analysis of genetic diversity and geographic variation in wild populations of the American chestnut (Fagaceae). American Journal of Botany 85: 1013-1021

Le Corre, V.;: Dumolin-Lapegue, S. and Kremer, A. 1997. Genetic variation at allozyme and RAPD loci in sessile oak Quercus petrea (Matt.) Liebl.: the role of history and geography. Mol. Ecol 6: 519-529.

Lynch, M. and Milligan, B.G. 1994. Analysis of population genetic structure with RAPD markers. Mol. Ecol. 3: 91-99.

Loewe, M.V.; Neuenschwander, A.A. and Alvear, S.C. 1994. El castaño en Chile: un cultivo promisorio. Documento Técnico $N^{\circ} 85$, Revista Chile Forestal.

Loewe, V.; López, C. and Urquieta, E. 1997. Identificación de zonas potenciales para el establecimiento de Castaño (Castanea sativa Mill.), VIII - X región. Proyecto FIA-FONSIP "Silvicultura de especies no tradicionales: una mayor diversidad productiva".

Nei, M. 1978. Estimation of average heterozygosity and genetic distance from a small number of individuals. Genetics 89: 583-590.

Swofford, D.L. and Selander, R.B. 1989. Biosys-1. Illinois natural History Survey.

Villani, F.; Pigliucci, M.; Benedettelli, S. and Cherubini, M. 1990. Genetic differentiation among Turkish chestnut (Castanea sativa Mill.) populations. Heredity 66: 131-136.

Villani, F.; Benedettelli, S.; Paciucci, M.; Cherubini, M. and Pigliucci, M. 1991. Genetic variation and 
differentiation between natural populations of chestnut (Castanea sativa Mill.) from Italy. In: Fineschi, S.; Malvolti, M.E.; Cannata, F. and Hattermer, H.H. (Eds.). Biochemical Markers in the Population Genetics of Forest Trees. Spb Academic Publishing, Hague, The Netherlands. Pp: 91-103.

Villani, F.; Pigliucci, M. and Cherubini, M. 1994. Evolution of Castanea sativa Mill. in Turkey and Europe. Genet. Res. Camb. 63:109-116.

Villani, F.; Cherubini, M. and Cannata, F. 1995. Comparison of Chestnut Genetics in France and Italy. In "Sustainability of Mediterranean Ecosystem: case study of the chestnut forest". Ecosystem Research Report 19 European Commission EUR 15727 EN. EdF. Romane. Pp: 89-103.

Villani, F.; Sansotta, A.; Cherubini, M.; Cesaroni, D. and Sbordoni, V. 1999. Genetic structure of natural populations of Castanea sativa in Turkey: evidence of a hybrid zone. J. Evol. Biol. 12: 233-244.

Weir, B.S. and Cockerham, C.C. 1984. Estimating F-statistics for the analysis of populations' structure. Evolution 38: 1358-1370.

Yeh, F.C.; Chang, K.X. and Yang, R.C. 1995. RAPD variation within and among natural populations of trebling aspen (Populus tremuloides Michx) from Alberta. Journal of Heredity 86:454-460

Yeh, F.C.; Yang, R.C.; Boyle, T.B.J.; Ye, Z.H. and Mao, J.X. 1997. Popgene, the user-friendly software for Population genetic Analysis. Molecular Biology and Biotechnology Center of Alberta, Alberta. 